\title{
Local Wisdom Based Learning in Elementary School in Curriculum 2013
}

\author{
Dian Eka Indriani ${ }^{1(*)}$, M. Sahid ${ }^{1}$, Bachtiar Syaiful Bachri², Umi Anugerah Izzati ${ }^{2}$ \\ ${ }^{1}$ ISTKIP PGRI Bangkalan, Jl. Soekarno Hatta No.52 Bangkalan, Madura, Indonesia 2Universitas Negeri Surabaya, Jl. \\ Lidah Wetan, Lakarsantri, Surabaya, Indonesia \\ "Corresponding author. Email: dianindrian79@stkippgri-bkl.ac.id
}

\begin{abstract}
This study aims to determine the existence of learning that uses the basis of local wisdom contained in the K13 curriculum textbooks provided by the government. The method uses a qualitative approach with a snowball sampling technique using two primary schools in 18 sub-districts in the Bangkalan district, East Java. The method used is content analysis by identifying the existence of local wisdom in textbooks from the government and interview method as triangulation. The result of the context analysis shows that it is clear there is such a significant effort from Government in emphasizing the value of Local wisdom into the media. Keywords: Local wisdom based learning, elementary school, curriculum 2013
\end{abstract}

\section{INTRODUCTION}

The challenges of education today are faced in the era of globalization by not eliminating the characteristics of Indonesian people as national identity. School can gain meaningful learning by strengthening the principles of global thinking and insight with actions based on local wisdom [1].

Current modernization, such as the entry of foreign cultures from outside, has given many changes in people's lives. However, the changes that occur precisely lead to many moral crises. Therefore, to repair the decline in manners and morals is the responsibility of all elements by increasing faith and loyalty. The ethical dilemma is creeping in and infecting this nation, almost all the nation's elements also feel it. Meanwhile, many "violence cultures" or the rise of economic and political problems, whether we realize it or not, have contributed to the weakening of the character of the nation's children so that noble values are sinking [2].

Wisdom comes from the word wisdom. According to the Big Indonesian Dictionary (KBBI), wisdom has two meanings, namely, know or comprehend. The second meaning is witty, smart and wise. Words of wisdom mean wise, scholarship as something that is needed in interacting. Local wisdom is a source of reference as values of life wisdom that contain ideas or wise thoughts and behaviors that can be practiced as guides in daily activities related to family, neighbors, and others who live around them, such a characterbuilding media for formal educational institutions like school [3].

Local wisdom can also be defined as a cultural synthesis created by local actors through an iterative process, internalization, and interpretation of religious and cultural teachings that are socialized in the form of norms and used as guidelines in daily life for the community. It can be said that local wisdom is a form of cultural characteristics or excellence of a particular community that is very important and related to all aspects of community life. The noble values related to local wisdom are (1) Love for God and the universe and its contents; (2) Responsibility, discipline, and independence; (3) Honestly; (4) respect and courtesy; (5) Affection and care; (6) Confidence, creativity, hard work, and never give up; (7) Justice and leadership; (8) Good and humble; (9) Peace tolerance, and unity [4].

In its application, the Government tries to insert the value of integrated local wisdom into subjects that are structured in integrated learning using the webbed model using the thematic Curriculum 2013(K-13). K-13 is a curriculum applied by the government in order to replace the previous curriculum, namely (KTSP) Education Unit Level Curriculum, which has been implemented for several years for approximately 6 years. K13 began to be performed even though it was gradually tested in 2013, which was implemented in several schools. Then in 2014, the 2013 curriculum began to be carried out at certain classes at the elementary school level such as classes I, II, IV, and V. The 2013 curriculum (K-13) has its own characteristics such as there are 3 aspects of assessment namely aspects of knowledge, elements of skills, and aspects of attitude and behavior [5] [6].

Based on this background, in this article, the author intends to examine deeper the extent to which local 
wisdom is used by the government in learning in primary schools.

\section{METHOD}

The research method is using a qualitative approach, with a media content analysis was conducted. The purpose of this study is to evaluate textbooks provided by the government in relation to the quality of the local wisdom based learning in Elementary School. The team determined the dimensions of local wisdom upon which texts should be evaluated. These dimensions were: culture, language, habits, way of life and religion, these social values relating to the local wisdom learning. The evaluation also considers the grade at which the information is provided and its appropriateness to the child's development stage, and the result will be a detailed report.

In conducting the content analysis of the school textbooks for Student, several stages were taken:

a. The book selection was made in steps: first, all books accredited by the Department of National Education were sought. Then interviews were conducted by visiting the schools among the headmasters and teachers in the research areas. The teachers were asked what books on related subjects that the school used for the corresponding grades and subjects. Second, in choosing the textbooks used in the analysis, we take the manual provided by the government because all sampling schools using the book. Then based on these data, books were selected, downloaded and bought. The books consisted of themes. Each researcher had access to books.

b. The team decided to be more focus on analyzing books for students in Year 4 because these books might contain more clearly related information on local wisdom learning based on interview results with professional teachers.

c. The content of the books was checked individually; every aspect of the book that has local wisdom information was marked. On the other hand, every aspect of the book that has local wisdom information and knowledge implicitly was noted (Total number of books analyzed: 27 ).

d. A module to evaluate the books was designed (Table 1). Five local wisdom dimensions were evaluated against coverage, accuracy, normative. For this exercise, only the coverage and efficiency of local wisdom information and knowledge were analyzed.

e. Each author independently evaluates the books and provide a mark for all of the content analyzed. And then, the chief researcher then gathering all information from each author, complied with all the information, and made a resume to understand what subject and provided descriptions on Local wisdom issues.

f. An individual scientific content analysis was also conducted simultaneously by Izzati, who is a psychologist, analyzed whether the right terminology was used and whether the accuracy of the information was appropriately correct.

\section{RESULT AND DISCUSSIONS}

In analyzing a book about local wisdom learning, the research team analyzed the contents of the national curriculum and evaluated whether there were words or sentences used that related to local wisdom learning and also looked for sentences that might be hidden but actually explained local wisdom. After the results of the interview, analysis produce and shows which classes, in what subjects and in what semesters information on local wisdom learning is given, a number of related books from various publishers are selected for analysis. In this case, the books chosen for study are revised K13 student textbooks on Year IV Elementary School from the government. Analysis tools for evaluating the books were developed by the research team, and 5 local wisdom areas were analyzed. The five fields are Religion; Culture; Language; Habits, and lifestyle. The scope, accuracy and normative aspects of the 5 information and material presented in the books were analyzed by members of the research team.

The revised K13 textbook for 2017 is the development of the K13 handbook published by the Ministry of Education and Culture [7][8]. These books for Elementary School provided by the government consists of 8 themes for early class namely Year 1, Year 2, and Year 3. And consist of 9 topics for upper class namely Year 4, Year 5 and Year 6, each theme consists of 3 sub-themes. This paper presents only the results of the analysis of the content of year IV elementary school books because the values of Local wisdom are presented most in this year IV student textbook. The following are the results of the analysis of the 2017 revised K13 student book Year 4 Elementary School.

Table 1. local wisdom value in the textbook year 4

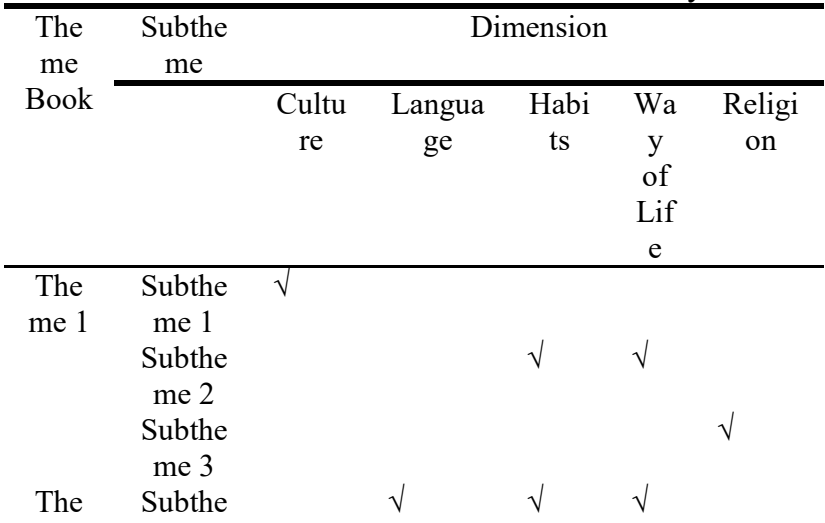




\begin{tabular}{ccccccc}
\hline $\begin{array}{c}\text { The } \\
\text { me } \\
\text { Book }\end{array}$ & $\begin{array}{c}\text { Subthe } \\
\text { me }\end{array}$ & \multicolumn{4}{c}{ Dimension } \\
& & Cultu & Langua & Habi & Wa & Religi \\
& & re & ge & ts & y & on \\
& & & & of & \\
& & & & \multicolumn{3}{c}{$\begin{array}{c}\text { Lif } \\
\text { e }\end{array}$} \\
& & & & & & \\
& & & & & &
\end{tabular}

\begin{tabular}{|c|c|c|c|c|c|c|}
\hline \multirow[t]{3}{*}{ me 2} & \multicolumn{6}{|l|}{ me 1} \\
\hline & $\begin{array}{l}\text { Subthe } \\
\text { me } 2\end{array}$ & & & $\sqrt{ }$ & & \\
\hline & $\begin{array}{c}\text { Subthe } \\
\text { me } 3\end{array}$ & $\sqrt{ }$ & & $\sqrt{ }$ & $\sqrt{ }$ & \\
\hline \multirow[t]{3}{*}{$\begin{array}{l}\text { The } \\
\text { me } 3\end{array}$} & $\begin{array}{l}\text { Subthe } \\
\text { me } 1\end{array}$ & & $\sqrt{ }$ & $\sqrt{ }$ & $\sqrt{ }$ & \\
\hline & $\begin{array}{l}\text { Subthe } \\
\text { me } 2\end{array}$ & $\sqrt{ }$ & $\sqrt{ }$ & $\sqrt{ }$ & $\sqrt{ }$ & \\
\hline & $\begin{array}{l}\text { Subthe } \\
\text { me } 3\end{array}$ & & $\sqrt{ }$ & $\sqrt{ }$ & $\sqrt{ }$ & \\
\hline \multirow[t]{3}{*}{$\begin{array}{l}\text { The } \\
\text { me } 4\end{array}$} & $\begin{array}{l}\text { Subthe } \\
\text { me } 1\end{array}$ & $\sqrt{ }$ & $\sqrt{ }$ & $\sqrt{ }$ & $\sqrt{ }$ & $\sqrt{ }$ \\
\hline & $\begin{array}{l}\text { Subthe } \\
\text { me } 2\end{array}$ & $\sqrt{ }$ & $\sqrt{ }$ & $\sqrt{ }$ & $\sqrt{ }$ & \\
\hline & $\begin{array}{l}\text { Subthe } \\
\text { me } 3\end{array}$ & $\sqrt{ }$ & & $\sqrt{ }$ & $\sqrt{ }$ & \\
\hline \multirow[t]{3}{*}{$\begin{array}{l}\text { The } \\
\text { me } 5\end{array}$} & $\begin{array}{c}\text { Subthe } \\
\text { me } 1\end{array}$ & $\sqrt{ }$ & $\sqrt{ }$ & $\sqrt{ }$ & $\sqrt{ }$ & $\sqrt{ }$ \\
\hline & $\begin{array}{l}\text { Subthe } \\
\text { me } 2\end{array}$ & $\sqrt{ }$ & & $\sqrt{ }$ & $\sqrt{ }$ & $\sqrt{ }$ \\
\hline & $\begin{array}{l}\text { Subthe } \\
\text { me } 3\end{array}$ & $\sqrt{ }$ & & $\sqrt{ }$ & $\sqrt{ }$ & $\sqrt{ }$ \\
\hline \multirow[t]{3}{*}{$\begin{array}{l}\text { The } \\
\text { me } 6\end{array}$} & $\begin{array}{c}\text { Subthe } \\
\text { me } 1\end{array}$ & $\sqrt{ }$ & & & & $\sqrt{ }$ \\
\hline & $\begin{array}{l}\text { Subthe } \\
\text { me } 2\end{array}$ & $\sqrt{ }$ & $\sqrt{ }$ & $\sqrt{ }$ & & $\sqrt{ }$ \\
\hline & $\begin{array}{l}\text { Subthe } \\
\text { me } 3\end{array}$ & $\sqrt{ }$ & & $\sqrt{ }$ & $\sqrt{ }$ & $\sqrt{ }$ \\
\hline \multirow[t]{3}{*}{$\begin{array}{l}\text { The } \\
\text { me } 7\end{array}$} & $\begin{array}{l}\text { Subthe } \\
\text { me } 1\end{array}$ & $\sqrt{ }$ & $\sqrt{ }$ & $\sqrt{ }$ & $\sqrt{ }$ & $\sqrt{ }$ \\
\hline & $\begin{array}{l}\text { Subthe } \\
\text { me } 2\end{array}$ & $\sqrt{ }$ & $\sqrt{ }$ & $\sqrt{ }$ & $\sqrt{ }$ & $\sqrt{ }$ \\
\hline & $\begin{array}{l}\text { Subthe } \\
\text { me } 3\end{array}$ & $\sqrt{ }$ & $\sqrt{ }$ & $\sqrt{ }$ & $\sqrt{ }$ & $\sqrt{ }$ \\
\hline \multirow[t]{3}{*}{$\begin{array}{l}\text { The } \\
\text { me } 8\end{array}$} & $\begin{array}{l}\text { Subthe } \\
\text { me } 1\end{array}$ & $\sqrt{ }$ & $\sqrt{ }$ & & $\sqrt{ }$ & $\sqrt{ }$ \\
\hline & $\begin{array}{l}\text { Subthe } \\
\text { me } 2\end{array}$ & $\sqrt{ }$ & $\sqrt{ }$ & $\sqrt{ }$ & $\sqrt{ }$ & $\sqrt{ }$ \\
\hline & $\begin{array}{l}\text { Subthe } \\
\text { me } 3\end{array}$ & $\sqrt{ }$ & $\sqrt{ }$ & $\sqrt{ }$ & $\sqrt{ }$ & $\sqrt{ }$ \\
\hline \multirow[t]{3}{*}{$\begin{array}{l}\text { The } \\
\text { me } 9\end{array}$} & $\begin{array}{l}\text { Subthe } \\
\text { me } 1\end{array}$ & $\sqrt{ }$ & $\sqrt{ }$ & $\sqrt{ }$ & $\sqrt{ }$ & $\sqrt{ }$ \\
\hline & $\begin{array}{l}\text { Subthe } \\
\text { me } 2\end{array}$ & $\sqrt{ }$ & & $\sqrt{ }$ & $\sqrt{ }$ & $\sqrt{ }$ \\
\hline & $\begin{array}{l}\text { Subthe } \\
\text { me } 3\end{array}$ & $\sqrt{ }$ & & $\sqrt{ }$ & $\sqrt{ }$ & $\sqrt{ }$ \\
\hline
\end{tabular}

Based on the table, we can see that in the student textbook Year 4 there is local wisdom value reviewed in theme books 1-9, and scattered in various sub-themes in each theme book for more details discussed in the following description. In the theme book 1 , the cultural dimension appears in sub-theme 1 and the aspects of habits and lifestyle in sub-theme 2 as well as the religious dimension in sub-theme 3 . Whereas in book theme 2 , there are dimensions of language, habits, and lifestyle discussed mixed in one essay, and habits in sub-theme 2, and culture, lifestyle, and habits reviewed in sub-theme 3 .

In the textbook with theme 3 , there is an emphasis on using proper language, communicating through discussions with parents, and various lifestyles of the community according to the chosen profession (farmers). Good habits that elevate the values of creativity and respect for others. The culture that emerged is about the traditional clothes of Papua, wearing feathers of paradise birds, lifestyle mutual cooperation, voluntary work, loving animals, caring for endangered animals inviting self-habit in environmental care appears in sub-theme 2; enjoy the environment on sub-theme 3, developing the habit of sharing and appreciating the work of others is also visible. The language aspect can be seen from the discussion material between friends and students' presentations to friends and parents.

On theme 4, there is a cultural dimension which is written in the symbol of Garuda with the symbol sound "Bhinneka Tunggal Ika," which means unity in diversity or different but still one." Religion is also implicitly contained in the symbol of the country that is the Garuda bird, which is displayed in sub-theme 1, namely the star symbol, and the explanation of the first precept that is God is One. It is emphasized with the content on religious tolerance, and the picture of children dressed in Muslim clothes. Culture also appears in the explanation and illustration of images about the martial art called Pencak Silat and beautiful art batik in sub-theme 1 .

The attitude of getting used to being honest is also discussed in articles that illustrate daily life in class. Subtheme 2 demonstrates the origin of the region, the lifestyle of mutual cooperation also appears in the essay about helping the cost of a child to participate in the speech contest implied in the following sentence "he said that the proceeds from the auction will be used to send Sudin to the speech contest in the city." Likewise, with the lifestyle of fishermen and several other professions, elements of local wisdom values are still included, such as saving natural resources and the importance of a clean lifestyle. Regarding language, it is emphasized with accent / accent from several regions such as Bali. Pencak silat is still the main topic in learning about culture coupled with the culture of greetings and weaving traditions. In sub-theme 3, there is folklore from West Kalimantan even though Pencak silat is still the main topic. It is an emerging mutual cooperation lifestyle.

In the book of theme 5 appears the religion adopted in Indonesia, as well as Muslim clothing used in illustrations. Regarding the culture introduced through the history of the kingdom of Mulawarman, Majapahit, 
and some pictures of dances and folk songs. Lifestyles of the community are explicitly stated in the explanation and symbol of the Pancasila precepts number 4. Local languages appear in the description of the hero of independence with the phrase "Sadumuk bathuk, sanyari bumi ditohi press starch," which means a finger of head, a span of land, defended to the death. Lifestyle and attitudes of daily habits are implicitly reviewed through the view of the struggle of the figures of freedom fighters. This appears in subtheme 1 and 2 . In subtheme 3 , the lifestyle of mutual cooperation explicitly, community service habits, apologizing, contributing to natural disasters are shown.

In the 6th theme book on religion and culture appears in illustrations and explanations of cultural diversity in various races and tribes in Indonesia such as gandrung Banyuwangi dances, Pendet dances from Bali, Saman dances, Piring or Plate dances and Remo dances from East Java and various custom home. Language appears in the phrase Bhinneka Tunggal Ika. The habit of helping appears in the illustration of the profession of a police officer. Good practices to dispose of garbage appear in sub-theme 3, places of worship, and figures of Muslim-style clothing and discussion of religious celebrations. Attitudes and lifestyles appear implicitly in essays.

The book Theme 7 is reviewing cultural diversity in more detail. The Cover page shows an illustration of the character using traditional clothes, also explaining the factor of difference in society, such as ethnicity in the table of ethnicity, religion, language, and transportation. Regional languages appear in the review of folk songs in the local song list table, and in the Sentences of Bhinneka Tunggal Ika presented and tables of Local words used by residents in the subtheme 1. Likewise, the diversity of Religion is further explored. Traditional transportation equipment and tools in people's lifestyles were also reviewed. Do not forget the dance tables, musical instruments and regional clothes are explained in subtheme 2. Fine arts, regional crafts, and religious matters and tolerance are more emphasized in subtheme 3. All dimensions of local wisdom appear in all subthemes.

In theme 8 , religion is introduced through the illustration of Muslim dress characters. Culture appears in folklore. Local languages also appear in traditional songs. Various domestic tourism and historical icons are outlined. The harmonious lifestyle is implied in the essays in sub-theme 1 . In sub-theme 2, there is an elaboration of a lifestyle of tolerance of religion and ethnicity, as well as the habit of holy work. Belief is shown by the character of women wearing hijab. The language also appears in the use of local Papuan songs. In sub-theme 3, religion appears in the illustrations of Muslim dress characters and explains the characteristics of the people. A thankful lifestyle is expressed in an essay on the life story of fishermen, and living in harmony, and tolerance appears in the explanation of the characteristics of the community. Culture emerges in the description of the role of folklore figures such as Gajahmada and Cindelaras, illustrations, and interpretations of the features of the various traditional fashions and traditional houses. The habit of prejudice appears explicitly in the explanation of the fiction of the golden jug and snake. Language appears in the expression Bhinneka Tunggal Ika which means Unity in Diversity.

On theme 9, religion appears in the cover illustration of Muslim dress characters. Language and culture emerge in the folk song Ayam Den Lapeh. The habits of cooperation and harmonious lifestyles are clearly described in subthemes-1 as well as language and culture displayed in folk songs and illustrations of traditional clothing and one new thing, namely conventional musical instruments in the form of a flute. In the sub-theme 2, dimensional of religion are outlined in the character illustration using the hijab, performing worship and religious ceremonies. The cultural dimension appears in pictures and explanations of regional dances and cultural festivals. The lifestyle of unity was also reviewed at a cultural festival and more clearly explained about tolerance and a family spirit. The custom of mutual cooperation is also written in sub-theme 2. Whereas in sub-theme 3 is showing culture in the form of regional art such as batik, wood carving. The habit of cleaning the house and the yard appears in the essay. Lifestyle is reviewed in an explanation of unity and harmony that is harmony in the family, community, and school. Culture dimension appears in the phrase festival of culture but is not reviewed further, batik as art also appears in the illustrations of advertising materials and explanations and how they are made. The lifestyle dimension appears in the description of the characteristics of living in harmony, and religion appears in the phrase emphasizing religious freedom and respect for fellow believers and illustrating the characters wearing Muslim clothing. The habit dimension also appears explicitly in the role model attitude.

\section{CONCLUSIONS}

The student textbook for Year 4 Elementary School provided by the government is using themes in emerging integrated learning. Hence, it is clear there is such a significant effort from the Government in emphasizing the value of Local wisdom into the media because this local wisdom is used as a guideline for the life of the community with local importance, but the values contained therein are universal. In book 4 itself, the local wisdom value learning is escalating from subtheme 1 to sub-theme 9. Such credit should be given to the authors for successfully displaying local wisdom in a smooth and well-structured manner. 
It is clear that if it is seen from the government's efforts to bring the values of local wisdom, the government seems to realize that the benefits of local knowledge are able to prevent radicalism. However, in the schools like in the island of Madura, namely in Bangkalan district, learning local wisdom remains inseparable from the culture of Pesantren as evidenced by the addition of additional subjects such as local content that is typical of boarding schools such as Hikam learning subjects, a Moslem holy book which are expected to be able to provide knowledge that is more deeply about religion. Therefore, it recommended further researches should be conducted.

\section{ACKNOWLEDGMENTS}

Our highest appreciation goes to DRPM since this paper is a part of research funded by DRPM in the PKPT scheme 2019.

\section{REFERENCES}

[1] R. S. Kusuma, 2018 Peran Sentral Kearifan Lokal Dalam Peningkatan Kualitas Pendidikan,“ Jurnal Pedagogik, pp. 230-239.

[2] N. L. Dewi, I. B. Putrayasa a I. G. Nurjaya, 2014 Analisis Nilai-nilai Pendidikan Karakter Novel Sepatu Dahlankarya Khrisna Pabichara Dan Relevansinya Terhadap Pengajaran Pendidikan Karakter Sekolahdi Indonesia,“ e-Jurnal Pendidikan Bahasa dan Sastra Indonesia, Undhiksa, pp. 1-10.

[3] Ghufronudin, A. Zuber a A. Demartoto, 2017 Representasi Pendidikan Karakter Berbasis Kearifan Lokal Melalui Pembelajaran Membatik, "Jurnal Analisa Sosiologi, pp. 3140.

[4] N. Asrianti, 2012 Pengembangan Karakter Peserta Didik Berbasis Kearifan Lokal Melalui Pembelajaran Di Sekolah,“ Jurnal Pendidikan Sosiologi dan Humaniora, p. 111.

[5] D. E. Indriani, 2016 Implementasi K13 dalam Proses Pembelajaran pada Anak Sekolah Dasar di Pulau Madura," rev. Profesionalisme Guru dan Dosen dalam Rangka Peningkatan Mutu Pendidikan, Bangkalan.

[6] D. E. Indriani, 2016 Assessment System in Curriculum 2013 of Elementary School in Sumenep District Madura Island,“ Journal of Education, Teaching and Learning, pp. 18-21.

[7] Mariatun, I. L., \& Indriani, D. E. (2018). Penguatan Pendidikan Karakter Berbasis Pancasila melalui Kurikulum K13 di Sekolah Dasar. Civic-Culture: Jurnal Ilmu Pendidikan PKN dan Sosial Budaya, 2(2), 153-160.

[8] A. S. Anggari, Afriki, D. R. Wulan, N. Puspitawati, L. M. 2017 Khasanah a S. Hendriyeti, Buku Tematik Terpadu Kurikulum
2013 edisi Revisi 2017, Jakarta: Kementerian Pendidikan dan Kebudayaan. 